\title{
New Data on Migration Time, Breeding Phenology, and Breeding Success of European Turtle Doves in Their Highest Breeding Habitats in North Africa
}

\author{
Ismail Mansouri $\mathbb{D}^{1},{ }^{1}$ Driss Ousaaid $\left(\mathbb{D},{ }^{2}\right.$ Wafae Squalli $\mathbb{D}^{1},{ }^{1}$ Abdelbari El Agy, ${ }^{1}$ \\ Abderahim EL-Hassani, ${ }^{1}$ Mohamed Mounir $\mathbb{D}^{3},{ }^{3}$ Lahsen Elghadraoui, ${ }^{1}$ \\ and Mohamed Dakki (iD) \\ ${ }^{1}$ Laboratory of Functional Ecology and Environment, Faculty of Sciences and Technology, \\ Sidi Mohamed Ben Abdellah University, P.O. Box 2202, Imouzzer Street, Fez, Morocco \\ ${ }^{2}$ Laboratory of Pharmacology and Environmental Health, Faculty of Science Dhar El Mahraz, USMBA Fez, B.P. 1796, \\ Fez-Atlas 30003, Morocco \\ ${ }^{3}$ Laboratory of Biotechnology and Valorisation of Phytogenetic Ressources, Faculty of Sciences and Technics, \\ Sultan Moulay Sliman University, Beni Mellal, Morocco \\ ${ }^{4}$ Laboratoire de Géo-biodiversité et Patrimoine Naturel, Scientific Institute, Mohamed V University, Av. Ibn Battota, 10 BP 703 , \\ Rabat, Morocco
}

Correspondence should be addressed to Ismail Mansouri; mankhori@gmail.com

Received 10 November 2020; Revised 27 January 2021; Accepted 6 February 2021; Published 23 March 2021

Academic Editor: Hynek Burda

Copyright (c) 2021 Ismail Mansouri et al. This is an open access article distributed under the Creative Commons Attribution License, which permits unrestricted use, distribution, and reproduction in any medium, provided the original work is properly cited.

\begin{abstract}
The migration dates, breeding phenology, and reproductive success of the European turtle doves were studied in the highest breeding habitats at Midelt (1400 to $1600 \mathrm{~m}$ ), Morocco. Data were recorded from March to October between 2015 and 2018, using the Common Bird Census methodology. Results showed that, at high-altitude breeding sites $(n=20)$, turtle doves arrived on $28.25 \pm 2.05 \mathrm{March}$, while departure dates were on $28.00 \pm 1.47$ September. On the other hand, nesting activity began on $26.5 \pm 0.64$ April, and laying dates were only two days after the nest construction date on $28.00 \pm 0.7$ April. First fledged chicks were $17.50 \pm 2.72$ May, and chicks started flying on $3.50 \pm 2.33$ June. In addition, breeding chronology, including nesting and chick's flight, was influenced by altitude and rainfall and more particularly controlled by temperature. For breeding success, among the 467 monitored nests, $73.87 \%$ survived during the nesting period and $71.16 \%$ of eggs have survived during incubation. Chicks' survival rate was higher with $79.56 \%$. Failure factors during breeding success were diverse. Predation caused the loss of $18.89 \%$ of eggs during incubation periods and $10.54 \%$ of chicks during the nestling phase. A few portions, including $4.41 \%$ of eggs and $4.39 \%$ of chicks, were deserted by their dove parents. Finally, our study highlights that the turtle dove breeds in high-altitude habitats with late and shorter breeding periods, which might allow this bird to avoid the vigorous climate conditions at mountains and their effect on reproductive success.
\end{abstract}

\section{Introduction}

The current advances in the study of avian migration have underscored the important linkages between wintering, stopover, and breeding zones [1-4] and the need to consider this interconnectivity in conservation measures [5]. It is becoming increasingly clear that the timing of spring migration, breeding chronology, and feeding quality can greatly influence reproductive success and population trends [6-8], especially for long-distance migratory species [9]. 
Birds are hypothesized to adopt their migration dates and breeding chronology in agreement with environmental factors dominating in wintering and breeding grounds [10]. This means that migration dates and breeding chronology were selected early and/or lately in order to avoid the harsh conditions, counting temperatures, and rainfall of such habitat [11]. In fact, many Anatidae and Palearctic migrant species have coincided their migration dates with suitable spring climate conditions and food availability during summer in breeding quarters, in order to maximize their breeding success [12]. Since climate change, mainly high temperatures can result in missed foraging opportunities, loss of body condition, and impaired parental care [13]. Also, avian responses to increasing temperatures may include breeding earlier in the season [14] or selecting cooler nest microsites [15].

With the development of technologies, especially satellite telemetry, the examination of individuals and their migration and/or breeding strategies facing different climatic, as well as geographical conditions, has greatly advanced with more abilities from wintering to breeding grounds [16, 17]. However, the field monitoring of the strategies adopted by these populations needs an exhaustive presence in the field $[18,19]$. Additionally, many ecological and biological aspects must be monitored for a long period before conclusions. This is particularly important in the case of rapidly declining species, where threatening factors are still unclear in both breeding and wintering zones [20, 21].

European turtle doves (Streptopelia turtur) are the only migrant Columbidae that winters in Sub-Saharan Africa and breeds in North Africa and Europe [22, 23]. Based on breeding and wintering areas, this game has undergone long-term declines, especially in Western Europe [24, 25]. Over the past decades, the intensification of agriculture and habitat loss are classified as principal causes leading to the declining of turtle doves $[22,26,27]$. These factors cause a failure of breeding success and reduction of migration capacities. Although the breeding ecology and migration dates of turtle doves have been examined in detail [28,29], there has been no comparable examination of the detailed breeding chronology and reproductive success in high-altitude habitats [22]. In all previous studies, research concerning breeding ecology was limited to an altitude ranging from 100 to $600 \mathrm{~m}$ in both Europe and North Africa [22, 23, 30-37]. Therefore, understanding the migration and breeding phenology at high-altitude habitat will open a new window in conservation measures, in particular with recent evidence indicating that turtle doves breed and feed in mountainous zones [22, 23]. In parallel, [38] have reported a significant shifting in migration dates and breeding chronology between high and low altitude breeding sites. Therefore, the clarification of migration dates and breeding success, as well as the impact of the principal environmental factors dominating, will situate the high-altitude zones in terms of suitability, mainly rate of breeding success, and in terms of habitat that deserves more attention in conservation concern for declining doves.

In this paper, we present a four-year analysis of breeding phenology and migration dates of turtle doves in their highest breeding habitats. We examine the evidence that elevations in altitudinal parameters have coincided with late migration dates and breeding chronology in doves as reported in many other avian species. In the Western Atlantic Red Knot (Calidris canutus rufa) and Savannah Sparrows (Passerculus sandwichensis), the migration and breeding chronology were late in high-altitude mountains and influenced rate of success $[39,40]$. Therefore, if the change in breeding chronology occurs, then how it will influence breeding success in the 'vulnerable' turtle dove.

\section{Methods}

2.1. Study Area. The present study was carried out in Midelt province, Ait Ayach valley $\left(32^{\circ} 41^{\prime} \mathrm{N}, 4^{\circ} 44^{\prime} \mathrm{W}\right)$ Morocco. The monitored sites were located at the Northern foot of Jbel Ayachi Mountains, in the Molouya high plateau, 1400 to $1600 \mathrm{~m}$ altitude above sea level (Figure 1). Midelt was dominated by forests that cover 17095 ha, including Xerophytes with 4772 ha, Holm oak 3375 ha, and Red juniper 2280 ha, while irrigated perimeter cover more than 1000 ha [33]. The orchards were dominated by fruit trees, including apples, plums, and peach trees.

In terms of climate, the temperature in Midelt ranges from 8 to $21.2^{\circ} \mathrm{C}$ with an annual average of $16.9^{\circ} \mathrm{C}$, and precipitations vary largely between $65 \mathrm{~mm}$ and $481 \mathrm{~mm}$ from one year to another (data were extracted from 1957 to 2010 from Midelt Weather Station). All these characteristics, including vegetation cover and climatic parameters, would play a major role in the bioecology of the turtle dove.

2.2. Data Collection. Twenty apple orchards ( 7.47 ha in total) at Ait Ayach (Midelt) were selected and monitored during four years, from 2015 to 2018 . For each season, the survey of dove's arrival dates (first observed birds during spring) started from early March and continued to the building of the first nest. Equally, departure dates (date of last observed birds in the breeding site) were recorded at the leaving of the last birds from the whole breeding area. After the installation of doves in the designated sites (after the arrival of breeding pairs), the nest initiation (first nest recorded after the arrival date), laying date (first egg after the nest initiation), hatching (first fledged chick), and chicks' nest leaving (first chick to leave its nest) were surveyed with three visits per month (each visit with three days in field), based on turtle dove breeding biology reported in North Africa [30, 31, 41, 42]: (i) the first visit was conducted at the beginning of every month, (ii) the second visit from $10^{\text {th }}$ to $20^{\text {th }}$ days, (iii) the third visit from $20^{\text {th }}$ to $30^{\text {th }}$ days. Common Bird Census (CBC) methodology [36], instigated to provide sound and observational information on farmland bird populations in agricultural lands, was used and research took place from 06.00 to 18.00 hours. In our case, this methodology was adopted inside apple orchards and nests or breeding pairs were researched line by line based on the tree lines of apple trees. In every single visit, recorded nests were monitored from the construction to the nest leaving or nest failure. Furthermore, reproductive success rates were evaluated by the calculation of hatching eggs (hatched eggs/laid eggs), fledging, and flying chicks (chicks leaving their nests/fledged chicks). 

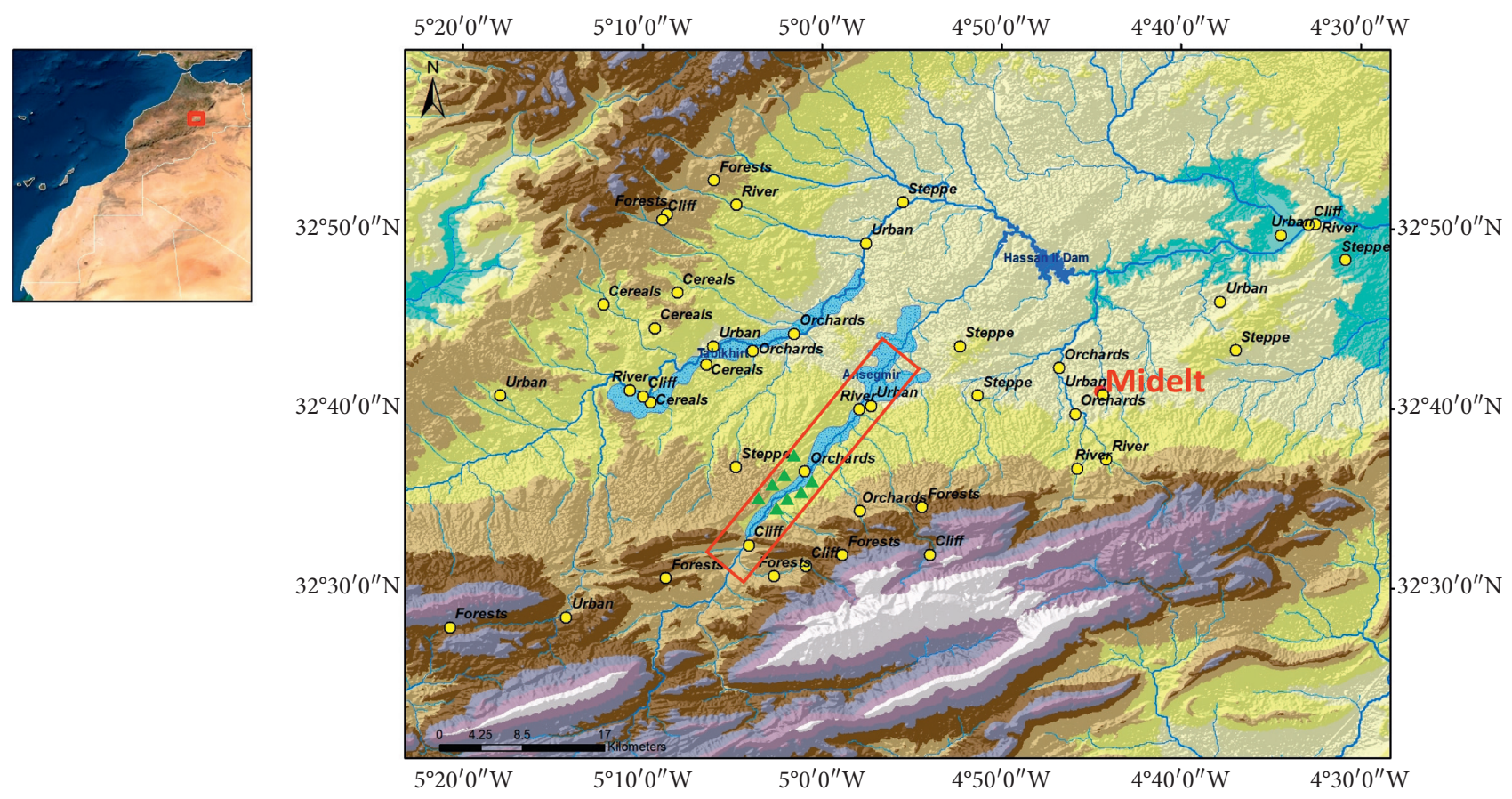

Coordinate system: GCS WGS 1984

Datum: WGS 1984

Units: degree

$\square$ Ayt ayach valley
$\square \quad$ Habitats
$\sim$ River
$\square$ Floodplain
$\square$ Hassan II Dam
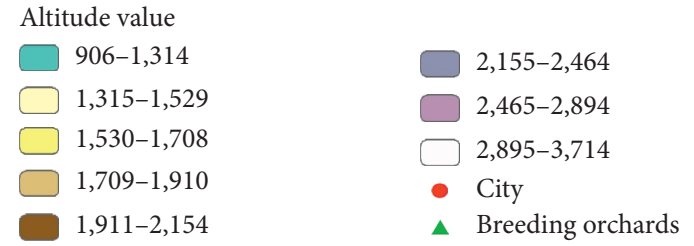

Figure 1: Studied orchards in Ait Ayach valley, Midelt province, Morocco, between 2015 and 2018.

Moreover, failure factors were cited (basing on carcasses and other aspects, such as the status of the nest and feathers in or outside the nest) along with breeding stages, in order to compare between breeding phases.

2.3. Data Analysis. The normality of data was checked for all variables with the Kolmogorov-Smirnov test. Arrival and departure dates were defined and means were calculated (all arrival or departure dates during four years). Results were given as mean \pm SD. Climatic conditions (temperature and rainfall) were accessed from the Midelt Weather Station from 2015 to 2018 . We analysed separately the relationship between breeding chronology, including nesting, laying, hatching, nest leaving and habitat characteristics, counting altitude, temperature, and rainfall by simple regression (linear model), and all variables with $P$ walue greater than 0.5 were eliminated. In parallel, the analysis of variance with the lack-of-fit test was conducted to evaluate the best-fit for models by considering chronology (nesting, laying, hatching, and nest leaving dates) as dependent variables and habitat parameters (altitude, temperature, and rainfall) as factors. Rates of breeding success were compared between breeding phases, including nesting, laying, and rearing, via one-way ANOVA test, considering twenty apple orchards.
Statistical analysis was performed using the STATGRAPHICS Centurion software (version XVI.I), and graphs were created by GraphPad Prism Mac 6.0 h software.

\section{Results}

3.1. Migration and Breeding Chronology. During four years, the first arrival dates in spring were on $28.25 \pm 2.05 \mathrm{March}$, while the last doves were observed on $28.00 \pm 1.47$ September at Midelt. On the other hand, turtle doves arrived solitary, particularly during the first weeks of April. After these periods, doves were observed in groups, especially in pairs.

The breeding chronology of turtle doves, including nest initiation, laying, fledging, and chick's flying dates at Midelt is summarized in Figure 2. Nesting (initiation of nest construction) began during the last week of April at Midelt $(26.5 \pm 0.64$ April), and the nesting period dated from 26 April to 6 August. Similarly, laying dates were earlier, and the first eggs were found on $28.00 \pm 0.7$ April, only two days after the nest construction date. The last laying date was on 12 August. On the other hand, the first fledged chicks were on $17.50 \pm 2.72$ May, and chicks started flying on $3.50 \pm 2.33$ June. 


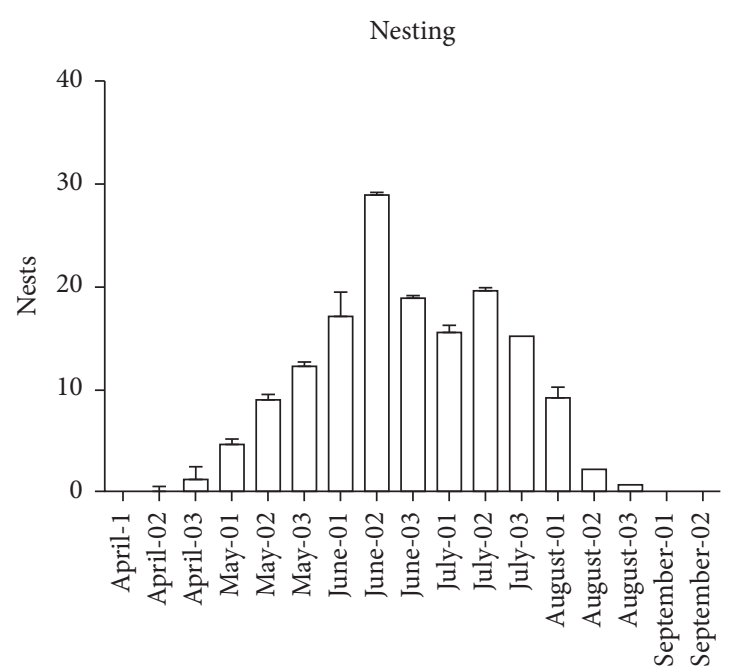

Dates (10 days)

hatching

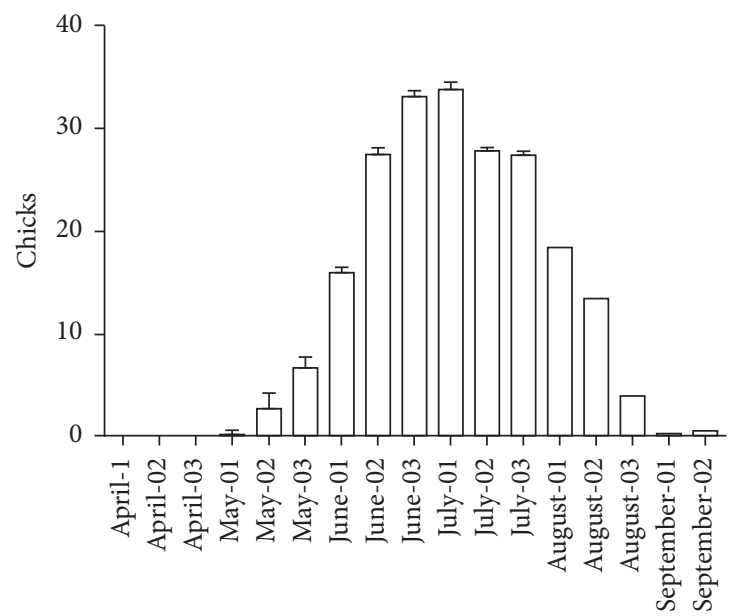

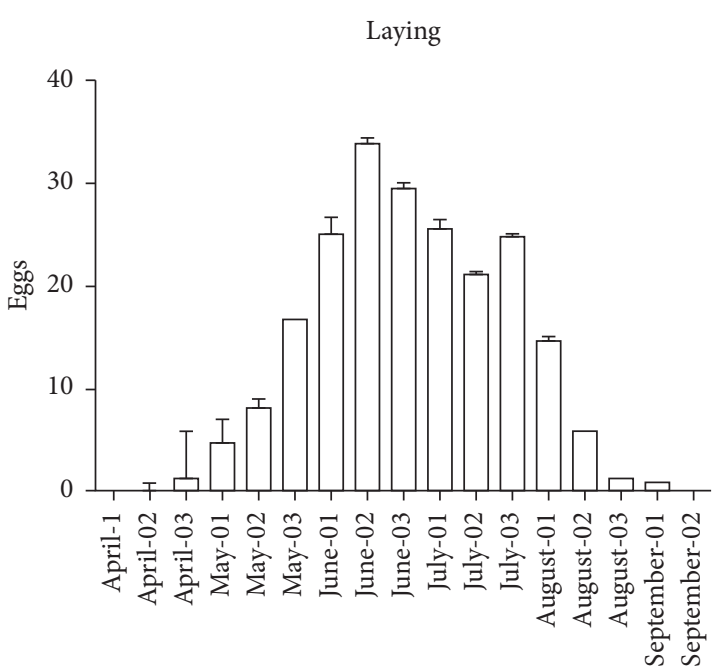

Dates (10 days)

nest leaving



FIGURE 2: Breeding chronology of turtle dove at Midelt between 2015 and 2018. (nesting: mean \pm SD number of nests by decades (10 days) from April to September; laying: mean \pm SD number of laid eggs by decades (10 days) from April to September; hatching: mean \pm SD number of hatched chicks by decades (10 days) from April to September; nest leaving: mean \pm SD number of chicks that survived by decades (10 days) from April to September).

3.2. Breeding Success. Among the 467 monitored nests at Midelt (Table 1), only $73.87 \%$ were survived. During the incubation stage, the hatching success rate was $71.16 \%$. In addition, during the rearing period, chicks' survival rate was higher with $79.56 \%$ of chicks ( $n=20$ (orchards), $F=3.696$, $P=0.031$ ). On the other hand, failure factors of breeding success were diverse. Predation presented the most risk menacing turtle dove's breeding success, causing loss of $18.89 \%$ of eggs during incubation periods and $10.54 \%$ of chicks during the nestling phase. Additionally, 5.03\% of eggs were unhatched and $5.49 \%$ of chicks have died inside their nests. Few portions, including $4.41 \%$ of eggs and $4.39 \%$ of chicks were deserted by their dove parents.

3.3. Relationships between Breeding Parameters and Climatic Conditions. The relationships between the breeding chronology of turtle doves (nest initiation, laying dates, and hatching dates) and climatic parameters at Midelt are summarized in Figure 3 and Table 2. The breeding chronology of turtle doves, mainly nesting dates were earlier with increasing temperatures. On the contrary, elevated altitudes and increasing temperatures shifted lately nesting and fledging dates of turtle doves at Midelt.

\section{Discussion}

Previous studies have noted that turtle doves breed in warm and lowlands, preferring farmlands and forests [31, 40, 43-47]. However, no previous effort has been made to investigate the breeding attempt in high-altitude habitats, particularly in North Africa [29].

Our findings clearly indicate that the European turtle doves breed in Midelt as a mountainous zone with an altitude ranging between 1400 and $1600 \mathrm{~m}$. This species arrived on $28.25 \pm 2.05$ March and started its breeding season 
Table 1: Breeding success of turtle doves from 2015 to 2018 at Midelt, Morocco.

\begin{tabular}{|c|c|c|c|}
\hline & Parameters & Number & $\%$ \\
\hline \multirow{4}{*}{ Nests } & Total & 467 & 100 \\
\hline & Succeed & 345 & 73.87 \\
\hline & Predated & 98 & 20.98 \\
\hline & Abandoned & 24 & 5.14 \\
\hline \multirow{6}{*}{ Eggs } & Total & 635 & 100 \\
\hline & Succeed & 455 & 71.16 \\
\hline & Predated & 120 & 18.89 \\
\hline & Abandoned & 28 & 4.41 \\
\hline & Destruction & 0 & 0 \\
\hline & Unhatched & 32 & 5.03 \\
\hline \multirow{5}{*}{ Chicks } & Total & 455 & 100 \\
\hline & Succeed & 362 & 79.56 \\
\hline & Predated & 48 & 10.54 \\
\hline & Died & 25 & 5.49 \\
\hline & Abandoned & 20 & 4.39 \\
\hline
\end{tabular}

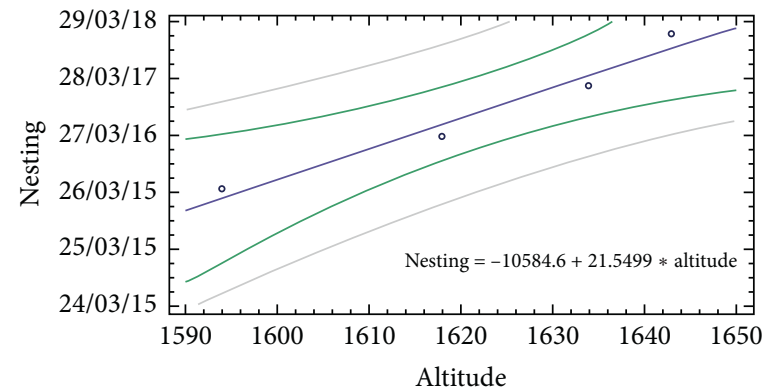

(a)

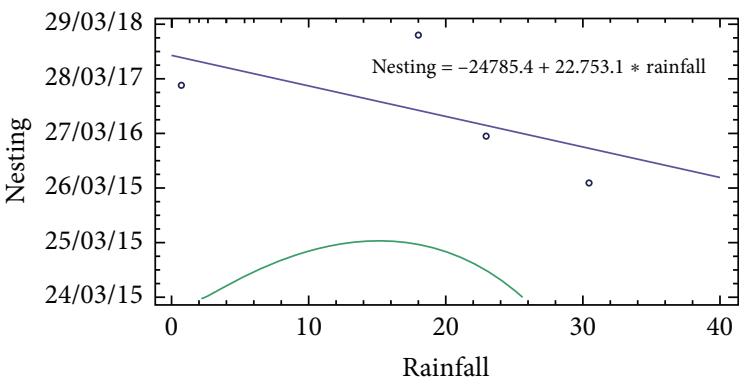

(c)

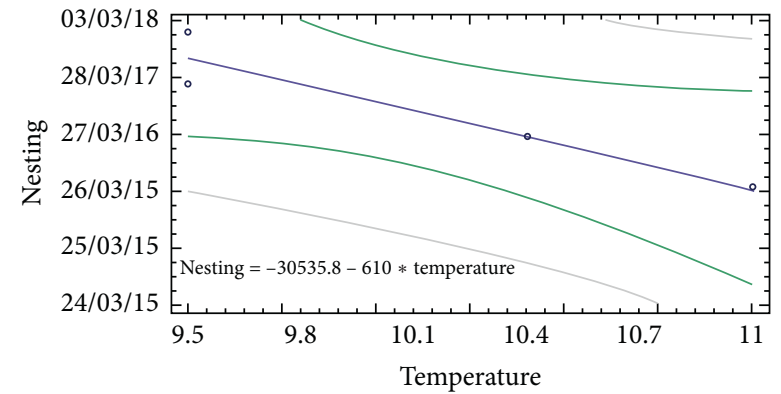

(b)

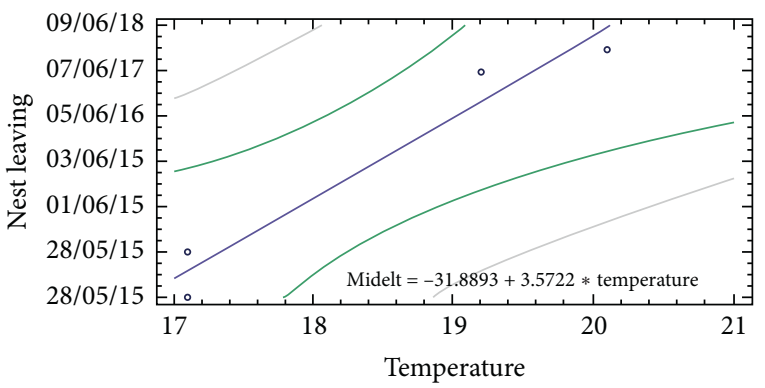

(d)

Figure 3: Relationship between the environmental factors and turtle dove chronology at Midelt during 2015 to 2018 . (a) Between nesting dates and altitude. (b) Between Nesting dates and temperature. (c) Between nesting dates and rainfall. (d) Between nest leaving dates and temperatures (the lack of fit test is designed to determine whether the selected model is adequate to describe the observed data).

TABLE 2: Models of the relationship between the breeding chronology of turtle doves (dates) and habitat conditions (altitude, temperature, and rainfall) during 2015 to 2018 (the lack of fit test is designed to determine whether the selected model is adequate to describe the observed variables).

\begin{tabular}{|c|c|c|c|c|c|}
\hline Model & Sum of squares & $D f$ & Mean square & $F$ & $P$ value \\
\hline Nesting $\times$ altitude & 643077 & 1 & 643077 & 47.51 & 0.0204 \\
\hline Nesting $\times$ temperature & 602802 & 1 & 602802 & 17.90 & 0.0516 \\
\hline Nesting $\times$ rainfall & 248772 & 1 & 248772 & 1.18 & 0.3907 \\
\hline Nest leaving $\times$ temperature & 88.1441 & 1 & 88.1441 & 38.27 & 0.0251 \\
\hline
\end{tabular}



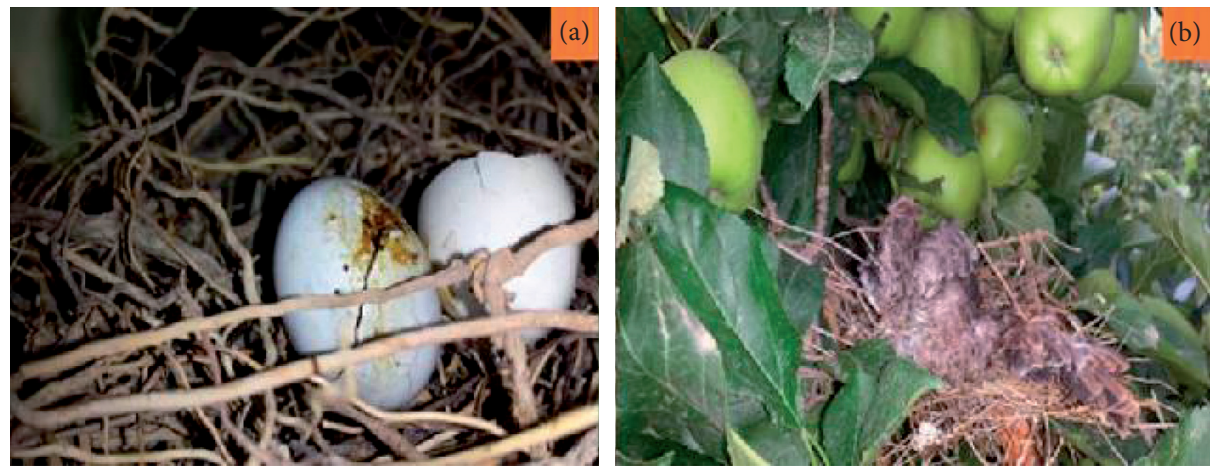

FIgURE 4: Predation of eggs (a) and chicks (b) of turtle doves in apple orchards during breeding seasons between 2015 and 2018.

by nesting activity on $26.5 \pm 0.64$ April. The laying period took place two days after nest initiation on $28.00 \pm 0.7$ April. This breeding chronology is in agreement with results cited by [33], while previous studies have noted a variation in the breeding chronology of turtle doves. At Tadla (514 m altitude and $150 \mathrm{~km}$ to Midelt), the first doves arrived early on $19 \pm 0.6$ March [48, 49], at Haouz (452 $\mathrm{m}$ altitude and $300 \mathrm{~km}$ to Midelt) 15 to 16 March [50], and in Moroccan North Atlantic (100 m above sea level and $450 \mathrm{~km}$ to Midelt) $24 \pm 0.16$ March [51]. In all these preceding studies, particularly those cited in low breeding sites (between $100 \mathrm{~m}$ and $514 \mathrm{~m}$ above sea level), nesting and laying dates ranged between 19 to 23 March and 10 to 20 April, respectively. Therefore, despite the limitation of this study to one highaltitude site, the cited literature confirms that the arrival and breeding chronology dates are later in high-altitude breeding lands. At this point, the latitudinal influence on arrival and breeding dates was excluded, because Tadla where Dove's chronology was earlier being in the same latitudinal level with Midelt, while the northern Atlantic is in the North of Midelt. The suggested reason behind this late breeding chronology at Midelt is the environmental factors accompanying the elevation of the altitude (Figure 3). In fact, high temperatures and low rainfall promote an early nesting and check nest leaving (Table 2). Such results were mentioned in many other migratory birds [52-54]. In the barn swallow (Hirundo rustica), the arrival dates vary from 12 April at 110 altitude to 24 April at $760 \mathrm{~m}$ [55]. Furthermore, the temperature was warm at lowlands and predicted the arrival dates of swallows. On the other hand, departure dates were on $28.00 \pm 1.47$ September, before the installation of cold temperatures in dove's breeding site.

Across three breeding seasons, breeding success was different from nesting to chicks rearing (Table 1). In total, $71.16 \%$ of eggs were hatched, and $79.56 \%$ of chicks have flown. Moreover, $57 \%$ of chicks (flown chicks/laid eggs) have flown at Midelt, which is comparable to previous results cited in other North African breeding habitats [35, 38, 45]. In Algeria, the nesting success varies between $56 \%$ and $60.32 \%$ $[36,37,46]$, and in Morocco success rate varies between 54,1 $\%$ and $55.5 \%[39,48,56]$. Failure factors were different. The predation (Figure 4), mainly reptiles, caused the loss of a significant clutch part (20.98 of nests were predated, counting $18.89 \%$ of eggs and $10.54 \%$ of chicks), as well as the desertion of nests (5.14\% of nests were deserted, counting 28 eggs (4.41\%) and 20 chicks (4.39\%)). Furthermore, 32 eggs were unhatched and 25 dead chicks were lost (chicks were found died every cold morning). Similar results were cited in Orange orchards. In fact, $[29,39,48]$ have reported that the human disturbance in orange orchards at Tadla $(150 \mathrm{~km}$ to Midelt) counting fruit harvesting, tree pruning, and the overuse of pesticides in coincidence with turtle dove breeding periods, are the main factors causing nest desertion.

\section{Conclusion}

In summary, this study provides a deep analysis of turtle doves' arrival dates, breeding chronology, and reproductive success in its North African highest breeding zone. Results reveal the late arrival and breeding seasons in high-altitude habitats compared to lowlands. However, breeding success was similar between low- and high-altitude zones. All these strategies, including late arrival and breeding chronology, prevent turtle doves against low temperatures in high habitats (protection of eggs and chicks) and human disturbance in managed agricultural farms.

\section{Data Availability}

The data used to support the findings of this study are included within the article.

\section{Conflicts of Interest}

The authors declare that there are no conflicts of interest regarding the publication of this paper.

\section{References}

[1] J. A. Gill, K. Norris, P. M. Potts, T. G. Gunnarsson, P. W. Atkinson, and W. J. Sutherland, "The buffer effect and large-scale population regulation in migratory birds," Nature, vol. 412, no. 6845, pp. 436-438, 2001.

[2] P. P. Marra, K. A. Hobson, and R. T. Holmes, "Linking winter and summer events in a migratory bird by using stable-carbon isotopes," Science, vol. 282, no. 5395, pp. 1884-1886, 1998. 
[3] I. Newton, "Can conditions experienced during migration limit the population levels of birds?" Journal of Ornithology, vol. 147, no. 2, pp. 146-166, 2006.

[4] R. Drent, C. Both, M. Green, J. Madsen, and T. Piersma, "Pay-offs and penalties of competing migratory schedules," Oikos, vol. 103, no. 2, pp. 274-292, 2003.

[5] D. W. Mehlman, S. E. Mabey, D. N. Ewert et al., "Conserving stopover sites for forest-dwelling migratory landbirds," The Auk, vol. 122, no. 4, pp. 1281-1290, 2005.

[6] R. H. Drent, G. Eichhorn, A. Flagstad, A. J. Van der Graaf, K. E. Litvin, and J. Stahl, "Migratory connectivity in arctic geese: spring stopovers are the weak links in meeting targets for breeding," Journal of Ornithology, vol. 148, no. 2, pp. 501-514, 2007.

[7] R. H. Drent, A. D. Fox, and J. Stahl, "Travelling to breed," Journal of Ornithology, vol. 147, no. 2, pp. 122-134, 2006.

[8] J. M. Black, J. Prop, and K. Larsson, Wild Goose Dilemmas: Population Consequences of Individual Decisions in Barnacle Geese, Branta Press, Carbondale, IL, USA, 2007.

[9] N. J. Murray, P. P. Marra, R. A. Fuller et al., "The large-scale drivers of population declines in a long-distance migratory shorebird," Ecography, vol. 41, no. 6, pp. 867-876, 2018.

[10] Y. Cheng, W. Fiedler, M. Wikelski, and A. Flack, "Closer-to-home" strategy benefits juvenile survival in a long-distance migratory bird," Ecology and Evolution, vol. 9, no. 16, pp. 8945-8952, 2019.

[11] C. Arzel, J. Elmberg, and M. Guillemain, "Ecology of spring-migrating Anatidae: a review," Journal of Ornithology, vol. 147, no. 2, pp. 167-184, 2006.

[12] W. Adams and W. M. Adams, "Migrant birds and the threatened sahel: geographies of land use and degradation," in Geography in Britain after World War II, M. Martin, V. Damodaran, and R. D’Souza, Eds., Palgrave Macmillan, Cham, Switzerland, 2009.

[13] V. Tm, M. Ae, and C. Sj, "High temperatures are associated with substantial reductions in breeding success and offspring quality in an arid-zone bird," Oecologia, vol. 193, no. 1, pp. 225-235, 2020.

[14] P. O. Dunn and D. W. Winkler, "Climate change has affected the breeding date of tree swallows throughout North America," in Proceedings of the Royal Society of London. Series B: Biological Sciences, pp. 2487-2490, London, UK, December 1999.

[15] J. B. Williams, H. J. van Noordwijk, and B. I. Tieleman, "Nest site selection in a hot desert: trade-off between microclimate and predation risk?" 2008.

[16] H. M. Williams, M. Willemoes, and K. Thorup, “A temporally explicit species distribution model for a long distance avian migrant, the common cuckoo," Journal of Avian Biology, vol. 48, no. 12, pp. 1624-1636, 2017.

[17] A. K. Townsend, B. Frett, A. McGarvey, and C. C. Taff, "Where do winter crows go? Characterizing partial migration of American crows with satellite telemetry, stable isotopes, and molecular markers," The Auk, vol. 135, no. 4, pp. 964-974, 2018.

[18] J. Zeng, Y. Liu, H. Zhang et al., "Global warming modifies long-distance migration of an agricultural insect pest," Journal of Pest Science, vol. 93, no. 2, pp. 569-581, 2020.

[19] N. R. Senner, M. Stager, and B. K. Sandercock, "Ecological mismatches are moderated by local conditions for two populations of a long-distance migratory bird," Oikos, vol. 126, no. 1, pp. 61-72, 2017.

[20] S. R. Curley, L. L. Manne, and R. R. Veit, "Differential winter and breeding range shifts: implications for avian migration distances," Diversity and Distributions, vol. 26, no. 4, pp. 415-425, 2020.

[21] D. Zurell, C. H. Graham, L. Gallien, W. Thuiller, and N. E. Zimmermann, "Long-distance migratory birds threatened by multiple independent risks from global change," Nature Climate Change, vol. 8, no. 11, pp. 992-996, 2018.

[22] I. Mansouri, W. Squalli, H. Sqalli, L. El Ghadraoui, D. Ousaaid, and M. Dakki, "The turtle dove (streptopelia turtur) in midelt plain, Morocco: nesting preferences and breeding success versus the impact of predation and agricultural practices," Journal of Animal Behaviour and Biometeorology, vol. 8, no. 3, pp. 206-214, 2020.

[23] C. Eraud, J.-M. Boutin, M. Riviere, J. Brun, C. Barbraud, and H. Lormee, "Survival of Turtle DovesStreptopelia turturin relation to western Africa environmental conditions," Ibis, vol. 151, no. 1, pp. 186-190, 2009.

[24] K. Risely, The Breeding Bird Survey 2010. BTO Research Report 597, British Trust for Ornithology Thetford, Thetford, England, 2011

[25] L. Moreno-Zarate, A. Estrada, W. Peach, and B. Arroyo, Spatial Heterogeneity in Population Change of the Globally Threatened European Turtle Dove in Spain: The Role of Environmental Favourability and Land Use, Diversity and Distributions - Wiley Online Library, Hoboken, NJ, USA, 2020.

[26] D. E. Chamberlain and R. J. Fuller, "Local extinctions and changes in species richness of lowland farmland birds in England and wales in relation to recent changes in agricultural land-use," Agriculture, Ecosystems \& Environment, vol. 78, no. 1, pp. 1-17, 2000.

[27] R. J. Fuller, "Relationships between recent changes in lowland British agriculture and farmland bird populations: an overview," Ecology and Conservation of Lowland Farmland Birds, vol. 1950, pp. 5-16, 2000.

[28] S. Dias, F. Moreira, P. Beja et al., "Landscape effects on large scale abundance patterns of turtle doves Streptopelia turtur in Portugal," European Journal of Wildlife Research, vol. 59, no. 4, pp. 531-541, 2013.

[29] S. Hanane, "The European turtle-doveStreptopelia turturin northwest Africa: a review of current knowledge and priorities for future research," Ardeola, vol. 64, no. 2, pp. 273-287, 2017.

[30] S. Hanane, "Plasticity in nest placement of the Turtle Dove (Streptopelia turtur): experimental evidence from Moroccan agro-ecosystems," Avian Biology Research, vol. 7, no. 2, pp. 65-73, 2014.

[31] H. Brahmia, A. Zeraoula, T. Bensouilah, Z. Bouslama, and M. Houhamdi, "Breeding biology of sympatric laughingStreptopelia senegalensisand turtleStreptopelia turturDove: a comparative study in northeast Algeria," Zoology and Ecology, vol. 25, no. 3, pp. 220-226, 2015.

[32] N. Saâd, S. Hanane, K. Farhi, and M. D. E. H. Khemis, "Nest age as predictor of nest survival in three sympatric dove species breeding in a mediterranean arid agroecosystem," Ardea, vol. 108, no. 2, pp. 1-12, 2020.

[33] I. Mansouri, M. K. Al-Sadoon, M. Rochdi, B. A. Paray, M. Dakki, and L. Elghadraoui, "Diversity of feeding habitats and diet composition in the turtle doves Streptopelia turtur to buffer loss and modification of natural habitats during breeding season," Saudi Journal of Biological Sciences, vol. 26, no. 5, pp. 957-962, 2019.

[34] N. Boukhemza-zemmouri, M. Belhamra, M. Boukhemza, S. Doumandji, and J.-F. Voisin, "Biologie de reproduction de la tourterelle des bois Streptopelia turtur arenicola dans le 
nord de l'algérie," Alauda Dijon, vol. 76, no. 3, pp. 207-222, 2008.

[35] J. Boukhriss, S. Selmi, and S. Nouira, "Bird nest predation in a southern Tunisian oasis habitat: no evidence of "edge effect"” Acta Oecologica, vol. 35, no. 2, pp. 174-181, 2009.

[36] X. Cabodevilla, L. Moreno-Zarate, and B. Arroyo, "Differences in wing morphology between juvenile and adult European turtle doves Streptopelia turtur: implications for migration and predator escape," Ibis, vol. 160, no. 2, pp. 458-463, 2018.

[37] H. Lormée, "Assessing the sustainability of harvest of the European turtle-dove along the European western flyway," Bird Conservation International, vol. 116 pages, 2019.

[38] I. Mansouri, M. Mounir, W. Squalli, L. Elhanafi, M. Dakki, and L. El Ghadraoui, "Migratory dates, breeding phenology, and reproductive success of European turtle doves between lowlands and highest breeding habitats in North Africa," International Journal of Zoology, vol. 21, 2020.

[39] K. Martin, S. Wilson, E. C. MacDonald, A. F. Camfield, M. Martin, and S. A. Trefry, "Effects of severe weather on reproduction for sympatric songbirds in an alpine environment: interactions of climate extremes influence nesting success," The Auk, vol. 134, no. 3, pp. 696-709, 2017.

[40] R. G. Lathrop, L. Niles, P. Smith et al., "Mapping and modeling the breeding habitat of the Western Atlantic red knot (Calidris canutus rufa) at local and regional scales," The Condor, vol. 120, no. 3, pp. 650-665, 2018.

[41] S. Hanane and L. Baamal, "Are Moroccan fruit orchards suitable breeding habitats for turtle dovesStreptopelia turtur?" Bird Study, vol. 58, no. 1, pp. 57-67, 2011.

[42] A. Kanza, Y. Farhi, Y. Halis, and M. Belhamra, "A comparison of the reproduction of collareddoves Streptopelia decaocto and turtle doves Streptopelia turtur in the ziban oases (Biskra, Algeria)," 2015.

[43] S. J. Browne and N. J. Aebischer, "Temporal changes in the breeding ecology of European turtle doves Streptopelia turtur in Britain, and implications for conservation," Ibis, vol. 146, no. 1, pp. 125-137, 2004.

[44] S. J. Browne, N. J. Aebischer, and H. Q. P. Crick, "Breeding ecology of turtle dovesStreptopelia turturin Britain during the period 1941-2000: an analysis of BTO nest record cards," Bird Study, vol. 52, no. 1, pp. 1-9, 2005.

[45] D. E. Bakaloudis, C. G. Vlachos, E. Chatzinikos, V. Bontzorlos, and M. Papakosta, "Breeding habitat preferences of the turtledove (Streptopelia turtur) in the dadia-soufli National park and its implications for management," European Journal of Wildlife Research, vol. 55, no. 6, p. 597, 2009.

[46] J. C. Dunn and A. J. Morris, "Which features of UK farmland are important in retaining territories of the rapidly declining turtle doveStreptopelia turtur?" Bird Study, vol. 59, no. 4, pp. 394-402, 2012.

[47] A. Gutierrez-Galan, A. L. Sanchez, and C. A. GonzáLez, "Foraging habitat requirements of European turtle dove Streptopelia turtur in a mediterranean forest landscape," Acta Ornithologica, vol. 53, no. 2, pp. 143-154, 2019.

[48] S. Hanane, P. Bergier, and M. Thevenot, "La reproduction de la tourterelle maillée Streptopelia senegalensis dans la plaine du tadla (maroc central): analyse comparée avec la tourterelle des bois Streptopelia turtur," Alauda Dijon, vol. 79, no. 1, pp. 17-28, 2011.

[49] S. Hanane and M. Benzyane, La Tourterelle Des Bois Au Maroc: Sur Les Traces D'un Gibier, Centre de Recherche Forestière, Rabat, Morocco, 2009.
[50] S. Hanane and M. Maghnouj, "Biologie de reproduction de la tourterelle des bois Streptopelia turtur dans le périmètre irrigué du Haouz (Marrakech-Maroc)," Alauda Dijon, vol. 73, no. 3, pp. 183-194, 2005.

[51] M. Thévenot and P. C. Beaubrun, "Statut et répartition actuelle des galliformes, charadriiformes et colombiformes nicheurs au Maroc," Symposium international sur la conservation et la gestion de la Faune sauvage méditérranéenne, vol. 12, pp. 16-18, 1983.

[52] K. Martin, S. Wilson, E. C. MacDonald, A. F. Camfield, M. Martin, and S. A. Trefry, "Effects of severe weather on reproduction for sympatric songbirds in an alpine environment: interactions of climate extremes influence nesting success," The Auk, vol. 134, no. 3, pp. 696-709, 2017.

[53] A. P. Møller, E. Flensted-Jensen, K. Klarborg, W. Mardal, and J. T. Nielsen, "Climate change affects the duration of the reproductive season in birds," Journal of Animal Ecology, vol. 79, no. 4, pp. 777-784, 2010.

[54] M. Ahola, T. Laaksonen, K. Sippola, T. Eeva, K. Rainio, and E. Lehikoinen, "Variation in climate warming along the migration route uncouples arrival and breeding dates," Global Change Biology, vol. 10, no. 9, pp. 1610-1617, 2004.

[55] T. H. Sparks and O. Braslavsk, "The effects of temperature, altitude and latitude on the arrival and departure dates of the swallow Hirundo rustica in the Slovak Republic," International Journal of Biometeorology, vol. 45, no. 4, pp. 212-216, 2001.

[56] F. Kafi, S. Hanane, T. Bensouilah, A. Zeraoula, H. Brahmia, and M. Houhamdi, "Les facteurs déterminant la réussite de la reproduction des tourterelles des bois (Streptopelia turtur) dans un milieu agricole Nord-Africain," Revue d Ecologie, vol. 70, no. 3, pp. 271-279, 2015. 